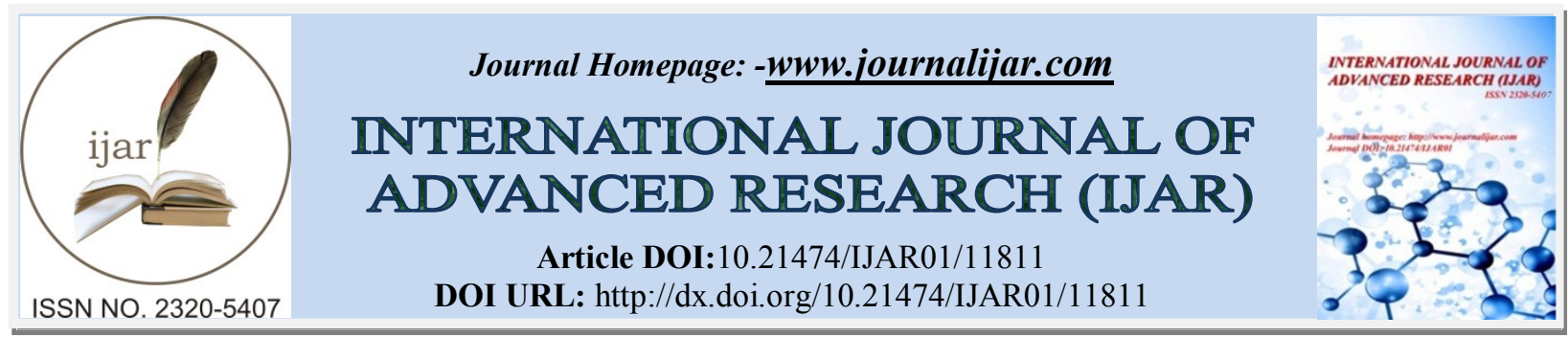

RESEARCH ARTICLE

\title{
INVESTOR'S CONSIDERATIONS TOWARDS INVESTMENT DECISIONS IN STOCK MARKET
}

\author{
Kuldeep Singh and Dr. S.S. Narta
}

1. Assistant Professor, Govt Degree College, Arki (Solan), H.P.

2. Professor, Department of Commerce, Himachal Pradesh University, Shimla, H.P.

\section{Manuscript Info}

(..........................

Manuscript History

Received: 26 July 2020

Final Accepted: 31 August 2020

Published: September 2020

Key words:-

Investment Decision, Return And Risk Factors

\begin{abstract}
Investment decisions are made keeping in view the return and risk factors in mind. Every investment decision involves the effective use of funds for future growth of funds. An investor's decision to make investment requires a careful analysis of prevailing condition and future prospects of market. Investment decision basically taken by investors depends upon the various factors. Normally investment decision is an attempt to plan properly, evaluate and allocate funds into various investment outlets that ensure investor's safety and expected rate of return. Investor's decision toward buying, selling and to keep/hold on particular security depend upon the various factors that affect the stock market. Present chapter deals with the factors that are taken into account while making investment in stock market.
\end{abstract}

Copy Right, IJAR, 2020,. All rights reserved.

\section{Introduction:-}

Investment in stock market depends upon the various factors i.e. tolerance of risk, selecting better securities, skill and understanding, volatility and hold on with previous investment etc. The results of investment decision directly linked with return on investment. Investment decision can prove your investment profitable as well as non profitable. The understanding and awareness level of investors play a vital role to grab all the relevant information and take investment decision within time. This paper aimed to take into account the consideration of investors while making investment in stock market.

\section{Review Of Literature:-}

(Shollapur\&Kuchanur, 2008), in their article, "Identifying perceptions and perceptual Gaps: A study on individual investors in selected investment avenues", emphasized that investors hold different perceptions on liquidity, profitability, collateral quality, statutory protection. The formation of perceptions triggers the investment process in its own way. This sometimes often leads to unrealistic apprehensions especially among individual investors. In addition, they also fix their own priorities for these perceptions. This study attempts calculate how far investors' agree with the selected perceptions as well as to find out the gaps between their perceptions and the underlying realities. Failure to deal with these gaps fends to lead the investment clientele towards a wrong direction. Hence, it was felt that there is a need to help for the investors to develop a realistic perspective of the investment avenues and their attributes.

Shi Jinyan, Li Yan and Li Yanxi (2011), in their article 'Research on the Enterprise Investment Behaviour and Economic consequence considering investors sentiment" analyse the influences of investor sentiment on enterprise investment behaviour and economic consequence. the study reveals that the relationship between investor 
sentiment and the enterprise investment behaviour is negative and that the relationship between investor sentiment and the enterprise growth one of the economic consequences, is U-shaped relationship.

\section{Objective Of The Study:-}

To examine the investment consideration of investors towards investment decision in stock market.

\section{Hypothesis Of The Study:}

H0: There is no significant difference between investors consideration on investment decision in stock market.

HA: There is a significant difference between investors consideration on investment decision in stock market.

\section{Need Of The Present Study:}

The present study assumes important because of the arrangement of funds by inducing the investors for investment decision and the result of that is capital formation which can be used in deficit sector of economy and that work for national progress. The ultimate aim of the present study is to know the investors consideration towards investment decision in stock market.

\section{Research Methodology And Data Collection:-}

The data collected in the form of questionnaire, responded by the respondents. The information collected was processed and tabulated suitably by highlighting all the variables taken for present study. Descriptive Statistical tools like mean, standard deviation, skewness, and kurtosis etc were used with the help of SPSS. In order to judge the significance of association between the two attributes i.e. to know the relationship between the consideration of investors and factor affecting investment decision in stock market, the chi-square test has been used which describe the magnitude of difference between observed frequencies and frequencies expected under certain assumptions. It merely evaluates the probability that the observed relationship results from chance. Further factor analysis has been used to reduce variables into factor. In the present study, large numbers of variables are considered to explain the factors affecting investment decision in stock market. The association among these interrelated variables are examined and represented in terms of few factors, which help in grouping the variables with similar characteristics together. In order to identify the factors affecting perception of investors while investing in stock market, a scale was developed comprising of statements. Further, the statements are measured on five point likert scale and on the basis of responses of investors; factor analysis will be able to extract the factors which effect the perception of investors in stock market.

Table 1:- Descriptive Statistics on Point for Consideration while Investing in Stock Market.

\begin{tabular}{|l|l|l|l|l|l|l|}
\hline Variables & Mean & $\begin{array}{l}\text { Standard } \\
\text { Deviation }\end{array}$ & Skewness & Kurtosis & $\begin{array}{l}\text { Chi- } \\
\text { Square }\end{array}$ & P-value \\
\hline Tolerance of Risk for High Return & 3.6692 & .84364 & -.414 & .628 & $283.272^{\mathrm{a}}$ & .000 \\
\hline High Risk Investment & 3.3206 & .86838 & -.201 & -.075 & $283.272^{\mathrm{a}}$ & .000 \\
\hline Consultancy for making Investment & 3.8270 & .84852 & -.745 & 1.115 & $302.738^{\mathrm{a}}$ & .000 \\
\hline $\begin{array}{l}\text { Comparison of Investors before } \\
\text { Picking Better stock }\end{array}$ & 3.6234 & .93168 & -.458 & -.091 & $302.738^{\mathrm{a}}$ & .000 \\
\hline $\begin{array}{l}\text { Skill and Understanding on Past } \\
\text { investment success }\end{array}$ & 3.4758 & .87776 & -.472 & .090 & $302.738^{\mathrm{a}}$ & .000 \\
\hline $\begin{array}{l}\text { Avoidance to make Investment in } \\
\text { Companies having poor earning history }\end{array}$ & 3.6896 & .87791 & -.443 & .293 & $302.738^{\mathrm{a}}$ & .000 \\
\hline $\begin{array}{l}\text { Comparison of current Stock Price with } \\
\text { Previous Low and High }\end{array}$ & 3.9949 & .83298 & -1.082 & 2.223 & $302.738^{\mathrm{a}}$ & .000 \\
\hline $\begin{array}{l}\text { Selling of stock which was hit light in } \\
\text { past year }\end{array}$ & 3.6590 & .84260 & -.728 & 1.114 & $302.738^{\mathrm{a}}$ & .000 \\
\hline Avoid to buy expensive Stock & 3.7506 & .83843 & -.573 & .899 & $302.738^{\mathrm{a}}$ & .000 \\
\hline $\begin{array}{l}\text { Hold on previous investment because } \\
\text { of poor market performance }\end{array}$ & 3.8524 & .76838 &.- .318 & -.018 & $302.738^{\mathrm{a}}$ & .000 \\
\hline Treatment of Investment Portfolio & 3.3333 & 1.04165 & -.115 & -.602 & $302.738^{\mathrm{a}}$ & .000 \\
\hline Concerned on price fluctuations & 3.6794 & .90295 &.- .452 & .127 & $302.738^{\mathrm{a}}$ & .000 \\
\hline $\begin{array}{l}\text { Satisfaction regarding Investment } \\
\text { decision }\end{array}$ & 4.0076 & .87040 & -.925 & 1.220 & $302.738^{\mathrm{a}}$ & .000 \\
\hline
\end{tabular}




\section{Source: Primary Probe}

The descriptive statistical analysis on factors that are given due consideration while making investment in stock market is presented in table 1. Mean score of responses on tolerance of risk for high return was found 3.66. The negative values of skewness reveals that the majority of responses are towards higher side of the mean value and the positive value of kurtosis depicts that the distribution of responses is Laptokurtic. Calculated value of Chi-Square is found significant at 1 percent significant level. Hence, it can be concluded that perception of investors on tolerance of risk for high return differ significantly.

The mean score of responses on high risk investment has been found 3.32 on five point Likert Scale. The negative values of skewness reveals that majority of responses are towards higher side of the mean value and the negative value of kurtosis depicts that the distribution of responses is Platykurtic. Calculated value of Chi-Square is found significant at 1percent significant level. Which shows that perception of investors towards willing high risk investment differ significantly.

Mean score of the responses on the issue of taking consultancy before making investment in stock market was found on higher side (3.86) than the average mean. The negative values of skewness reveals that the majority of responses are towards higher side of the mean value. The positive value of kurtosis depicts that the distribution of responses is Laptokurtic. Calculated value of Chi-Square found significant at 1percent significant level. Hence, it can be concluded that perception of investors in term of consultancy for making investment differ significantly.

Mean score of responses on making comparison for picking better stock has been found above average (3.62).The negative values of skewness reveals that the majority of responses are towards higher side of the mean value. The negative value of kurtosis depicts that the distribution of responses is Platykurtic. Calculated value of Chi-Square was found significant at 1 percent significant level. Which shows that perception of investors towards picking better stock differ significantly.

Responses of investors on skill and understanding of investors on past investment decision and treatment on investment portfolio has been found slightly higher than average score. The negative values of skewness reveals that the majority of responses are towards higher side of the mean value and positive value of kurtosis depicts that the distribution of responses is Laptokurtic and the calculated value of Chi-Square has been found significant at 1 percent significant level. Hence, it can be concluded that perception of investors in term of skill and understanding on past investment in stock market differ significantly.

Majority of respondents avoid to make investment in companies having poor past earning history, as the mean score of responses has been found higher (3.86) than the average score. The negative values of skewness reveals that the majority of responses are towards higher side of the mean value. The positive value of kurtosis depicts that the distribution of responses is Laptokurtic and further calculated value of Chi-Square is found significant at 1 percent significant level, which shows that perception of investors on avoiding to invest in companies having past poor earning history differ significantly.

Mean score of responses of investors as compare to current stock price with previous price was found high (3.99). The negative values of skewness reveals that the majority of responses are towards higher side of the mean value and positive value of kurtosis depicts that the distribution of responses is Laptokurtic. Further, calculated value of Chi-Square is found significant at 1 percent significant level, which shows that perception of investors in making comparison of current stock price with previous low and high price differ significantly.

Further majority of investors are of the opinion that they sell stock which hit low in past year as the mean score of responses in this regard was found (3.65). The negative values of skewness reveals that the majority of responses are towards higher side of the mean value and the positive value of kurtosis depicts that the distribution of responses is Laptokurtic. Calculated value of Chi-Square has been found significant at 1 percent significant level. Which depicts that perception of investors to sell stock which hit low in past year differ significantly.

Majority of the respondents feel that they avoid to buy expensive stock as the mean score of responses in this regard was found 3.75. The negative values of skewness reveal that majority of responses are towards higher side of the mean value and the positive value of kurtosis depicts that the distribution of responses is Laptokurtic. Further, 
calculated value of Chi-Square is found significant at 1percent significant level as perception of investors on buying expensive stock differ significantly.

Mean score of responses of investors who want to stay with previous investment was found 3.85 which is higher than the average mean score and the negative values of skewness reveals that the majority of responses are towards higher side of the mean value. The negative value of kurtosis depicts that the distribution of responses is Platykurtic and the calculated value of Chi-Square has been found significant at 1 percent significant level, which shows that responses of investors differ significantly on the issue of holding existing investment due to poor market performance.

Further mean score of the responses of investors on treatment of investment portfolio was found high (3.89). The negative values of skewness reveal that the majority of responses are towards higher side of the mean value and the negative value of kurtosis depicts that the distribution of responses is Platykurtic. Further the value of Chi-Square was found significant at 1 percent significant level. Hence, it can concluded that responses of investors on treatment of Investment portfolio differ significantly.

Respondents who are concerned about price fluctuations in stock market, their mean score has been found 3.67.The negative values of skewness reveals that majority of responses are towards higher side of the mean value and the positive value of kurtosis depicts that the distribution of responses is Laptokurtic. Further calculated value of ChiSquare has been found significant at 1 percent significant level, which shows that perception of investor differ significantly on the issue of fluctuations in the prices of the stock.

Overall investors have been found highly satisfied with their experiences on investment in stock market (4.00). The negative values of skewness reveals that the majority of responses are towards higher side of the mean value and positive value of kurtosis depicts that the distribution of responses is Laptokurtic.

\section{Exploratory Factor Analysis (EFA):}

Factor analysis also known as data reduction technique which includes two different steps i.e. Extraction of factors and Rotation of factors. The basic assumption while applying factor analysis is to ensure that variable should be highly correlated or related which means that there should be high level of multi- collinearity in the data set. For the purpose carrying out the factor analysis over a data set the following steps are involved in SPSS.

Analysis $>$ Dimension Reduction $>$ Factor $<$

Firstly click on descriptive dialogue on SPSS then by default initial solution already clicked choose KMO and Bartlett's test of Sphericity in order to check the stresses of the factor analysis solution. KMO and Bartlett's test signifies and tells whether sufficienct number of items is there in every variable or not. As the significance value of correlation matrix is checked through Bartlett's test of Sphericity and it indicates with the help of p-value parallel to the chi-square statistics.

The results of the Kaiser-Meyer-Olkin $(\mathrm{KMO}=.727)$ and Bartlertt's test of Sphericity with highly significant value clearly indicates the appropriateness of the use of factor analysis.

Table 2:- KMO and Bartlett's Test.

\begin{tabular}{|l|l|l|}
\hline Kaiser-Meyer-Olkin Measure of sampling Adequacy. & \multicolumn{2}{|c|}{.727} \\
\hline \multirow{2}{*}{ Bartlett's Test of Sphericity } & $\begin{array}{l}\text { Approx. Chi- } \\
\text { Square }\end{array}$ & 302.557 \\
\cline { 2 - 3 } & Df & 78 \\
\cline { 2 - 3 } & Sig. & .000 \\
\hline
\end{tabular}

Significant at .01level of confidence

\section{Communalities:}

Communalities are the degree of variance which a variable share with other variables and variables with high extraction values are well represented while variables with low extraction values are not well suited for factor analysis. Communalities for the selected variables under factor analysis have been found high extraction values which show that data is reliable for factor analysis. 
Table 3:- Communalities.

\begin{tabular}{|c|c|c|}
\hline Variables & Initial & Extraction \\
\hline Tolerance of Risk for High Return & 1.000 & .683 \\
\hline Comparision amongs Investors for willing High Risk Investment & 1.000 & .718 \\
\hline Consultancy for making Investment & 1.000 & .573 \\
\hline Comparison amongs Investors for Picking Better stock & 1.000 & .644 \\
\hline Skill and Understanding regarding Past investment success & 1.000 & .533 \\
\hline Avoidance to make Investment Companies having poor earning History & 1.000 & .481 \\
\hline Comparison of current Stock Price with Previous Low and High & 1.000 & .525 \\
\hline $\begin{array}{l}\text { Perception regarding decision for sell of stock which was hit light in } \\
\text { past year }\end{array}$ & 1.000 & .537 \\
\hline Perception regarding to avoid to buy expensive Stock & 1.000 & .516 \\
\hline $\begin{array}{l}\text { Action regarding stay on previous investment coz of poor market } \\
\text { performance }\end{array}$ & 1.000 & .722 \\
\hline Treatment of Investment Portfolio Element & 1.000 & .672 \\
\hline Concerned regarding price change for next investment & 1.000 & .538 \\
\hline Satisfaction regarding Investment decision & 1.000 & .691 \\
\hline
\end{tabular}

Source: Data collected through questionnaire.

Table 3 reveals that six factors with greater than one Eigen values are retained out of total thirteen variables. The percentages of variances indicate that the total variance attributed and cumulative percentage of variation as shown by these six variables is 60.261 percent. The first factor explains 13.561 percent of variance, second factor explains 11.635 percent of variance, third factor explains 10.361 percent of variance, fourth factor explains 8.643 percent of variance, fifth factor explains 8.162 percent of variance and sixth factor explains 7.898 percent of variance and the remains seven factors under factor analysis are insignificant.

Table 4:- Total Variance Explained.

\begin{tabular}{|c|c|c|c|c|c|c|c|c|c|}
\hline \multirow[b]{2}{*}{ Component } & \multicolumn{3}{|c|}{ Initial Eigen values } & \multicolumn{3}{|c|}{$\begin{array}{l}\text { Extraction Sums of Squared } \\
\text { Loadings }\end{array}$} & \multicolumn{3}{|c|}{$\begin{array}{l}\text { Rotation Sums of } \text { Squared } \\
\text { Loadings }\end{array}$} \\
\hline & Total & $\begin{array}{l}\% \text { of } \\
\text { Variance }\end{array}$ & $\begin{array}{l}\text { Cumulative } \\
\%\end{array}$ & Total & $\begin{array}{l}\% \text { of } \\
\text { Variance }\end{array}$ & $\begin{array}{l}\text { Cumulative } \\
\%\end{array}$ & Total & $\begin{array}{l}\% \text { of } \\
\text { Variance }\end{array}$ & $\begin{array}{l}\text { Cumulative } \\
\%\end{array}$ \\
\hline 1 & 1.763 & 13.561 & 13.561 & 1.763 & 13.561 & 13.561 & 1.547 & 11.898 & 11.898 \\
\hline 2 & 1.513 & 11.635 & 25.196 & 1.513 & 11.635 & 25.196 & 1.360 & 10.460 & 22.358 \\
\hline 3 & 1.347 & 10.361 & 35.557 & 1.347 & 10.361 & 35.557 & 1.305 & 10.042 & 32.400 \\
\hline 4 & 1.124 & 8.643 & 44.200 & 1.124 & 8.643 & 44.200 & 1.272 & 9.783 & 42.183 \\
\hline 5 & 1.061 & 8.162 & 52.362 & 1.061 & 8.162 & 52.362 & 1.230 & 9.464 & 51.647 \\
\hline 6 & 1.027 & 7.898 & 60.261 & 1.027 & 7.898 & 60.261 & 1.120 & 8.613 & 60.261 \\
\hline 7 & .954 & 7.335 & 67.596 & & & & & & \\
\hline 8 & .868 & 6.676 & 74.272 & & & & & & \\
\hline 9 & .806 & 6.198 & 80.471 & & & & & & \\
\hline 10 & .772 & 5.940 & 86.410 & & & & & & \\
\hline 11 & .658 & 5.059 & 91.469 & & & & & & \\
\hline 12 & .571 & 4.393 & 95.861 & & & & & & \\
\hline 13 & .538 & 4.139 & 100.000 & & & & & & \\
\hline
\end{tabular}

Source: Data collected through questionnaire

\section{Extraction Method:}

Principal Component Analysis.

\section{Component Matrix:}

Component matrix uses factor extraction method in extracting the combination of variables that explains the greatest amount of variance. Table 4 depicts the loadings of thirteen variables on the six factors extracted where factor one contributes the most followed by second, third, fourth, fifth and sixth in descending order. 
Table 5:- Component Matrix.

\begin{tabular}{|c|c|c|c|c|c|c|}
\hline \multirow[t]{2}{*}{ Variables } & \multicolumn{6}{|c|}{ Component } \\
\hline & 1 & 2 & 3 & 4 & 5 & 6 \\
\hline $\begin{array}{l}\text { Comparison among Investors for Picking Better } \\
\text { stock(4) }\end{array}$ & .621 & .251 & .108 & .285 & -.302 & .104 \\
\hline $\begin{array}{l}\text { Avoidance to make Investment Companies } \\
\text { having poor earning History }(6)\end{array}$ & .576 & .060 & -.197 & .203 & -.043 & .253 \\
\hline Consultancy for making Investment(3) & .559 & -.143 & .349 & -.217 & -.176 & .200 \\
\hline $\begin{array}{l}\text { Comparison of current Stock Price with Previous } \\
\text { Low and High }(7)\end{array}$ & .466 & -.026 & .262 & .182 & .451 & .048 \\
\hline $\begin{array}{l}\text { Perception regarding to avoid to buy expensive } \\
\operatorname{Stock}(9)\end{array}$ & .211 & .591 & -.294 & .051 & .169 & -.062 \\
\hline $\begin{array}{l}\text { Concerned regarding price change for next } \\
\text { investment(12) }\end{array}$ & .100 & .586 & -.236 & -.203 & -.294 & -.041 \\
\hline Treatment of Investment Portfolio Element(11) & -.325 & .512 & .065 & .481 & .251 & .078 \\
\hline Tolerance of Risk for High Return(1) & .041 & .143 & .678 & -.360 & .134 & .233 \\
\hline $\begin{array}{l}\text { Perception regarding decision for sell of stock } \\
\text { which was hit light in past year( } 8)\end{array}$ & .028 & .171 & .478 & .361 & .223 & -.313 \\
\hline $\begin{array}{l}\text { Skill and Understanding regarding Past } \\
\text { investment success(5) }\end{array}$ & -.331 & .141 & .469 & .048 & -.320 & -.280 \\
\hline $\begin{array}{l}\text { Action regarding stay on previous investment } \\
\text { coz of poor market performance }(10)\end{array}$ & -.038 & .412 & -.059 & -.566 & .466 & .098 \\
\hline Satisfaction regarding Investment decision(13) & .325 & .263 & .074 & -.248 & -.183 & -.645 \\
\hline $\begin{array}{l}\text { Comparison among Investors for willing High } \\
\text { Risk Investment(2) }\end{array}$ & -.371 & .403 & .204 & .034 & -.366 & .491 \\
\hline
\end{tabular}

Extraction Method:

Principal Component Analysis

Rotated Component Matrix:

To modify and refine the study and for better improvement in interpretability, the variables are rotated by using varimax rotation to find the underlying constructs and their relationship. The variables included under study represent the important factors that relates to investment decision. The results of rotated component matrix from table 5 identifies six important components which are most correlated.

Tables 6:- Rotated Component Matrix.

\begin{tabular}{|l|l|l|l|l|l|l|}
\hline \multicolumn{2}{|l|}{ Variables } & \multicolumn{2}{l|}{ Component } \\
\cline { 2 - 7 } & 1 & 2 & 3 & 4 & 5 & 6 \\
\hline $\begin{array}{l}\text { Comparison amongs Investors for Picking } \\
\text { Better stock(4) }\end{array}$ & .764 & -.014 & .095 & .053 & .114 & .189 \\
\hline $\begin{array}{l}\text { Avoidance to make Investment Companies } \\
\text { having poor earning History(6) }\end{array}$ & .652 & .112 & -.132 & -.065 & -.099 & -.109 \\
\hline $\begin{array}{l}\text { Action regarding stay on previous investment } \\
\text { because of poor market performance(10) }\end{array}$ & -.269 & .719 & -.076 & .343 & -.093 & -.022 \\
\hline $\begin{array}{l}\text { Perception regarding to avoid to buy } \\
\text { expensive Stock(9) }\end{array}$ & .235 & .618 & .018 & -.190 & .164 & .121 \\
\hline $\begin{array}{l}\text { Concerned regarding price change for next } \\
\text { investment(12) }\end{array}$ & .178 & .467 & .377 & -.110 & -.126 & .344 \\
\hline $\begin{array}{l}\text { Comparison among Investors for willing } \\
\text { High Risk Investment(2) }\end{array}$ & .017 & .056 & .800 & .156 & .073 & -.212 \\
\hline $\begin{array}{l}\text { Comparison of current Stock Price with } \\
\text { Previous Low and High(7) }\end{array}$ & .326 & .064 & -.463 & .293 & .314 & -.128 \\
\hline $\begin{array}{l}\text { Skill and Understanding regarding Past } \\
\text { investment success(5) }\end{array}$ & -.247 & -.287 & .385 & .133 & .315 & .353 \\
\hline Tolerance of Risk for High Return(1) & -.070 & .046 & .123 & .803 & .128 & .002 \\
\hline
\end{tabular}




\begin{tabular}{|l|l|l|l|l|l|l|}
\hline Consultancy for making Investment(3) & .447 & -.173 & -.094 & .522 & -.218 & .126 \\
\hline $\begin{array}{l}\text { Decision to sell stock which was hit in past } \\
\text { year(8) }\end{array}$ & .011 & -.106 & -.121 & .136 & .682 & .168 \\
\hline $\begin{array}{l}\text { Treatment of Investment Portfolio } \\
\text { Element(11) }\end{array}$ & -.048 & .277 & .272 & -.187 & .651 & -.245 \\
\hline $\begin{array}{l}\text { Satisfaction regarding Investment } \\
\text { decision(13) }\end{array}$ & .065 & .142 & -.129 & .029 & .031 & .805 \\
\hline
\end{tabular}

Table 6 reports loading of different statements as defined through six factors. First factor i.e. Knowledge about Investment Decision includes making comparison for picking better stock and avoidance to make investment in stock having poor earning history explain (11.898) percent of variance and the factor loading of these variables are 0.764 and 0.652 respectively, which means approximately 11.898 percent of variance in any one of the original variable is captured by extracted factor. The variables which are loaded on second factor i.e. Awareness about Investment Decision includes holding the stock because of poor market performance and to buy expensive stock explain 10.460 percent of variance and factor loading of these variables are, 0.719 and 0.618 respectively and the communality of factors one and two are 22.358 percent.

The variables which are loaded on third factor i.e. Understanding of Investment Decision include comparing high risky stock explain total of 10.042 percent of variance and the communality of factors one, two and three are 32.400 percent.

The variables which are loaded on fourth factor i.e. Professional Skill in Investment Decision include: Tolerance of Risk for High Return and Consultancy help in and making Investment and explains of 9.783 percent of variance and factor loading of these variables are 0.803 and 0.522 percent respectively and the communality of factors one, two, three and four are 42.183 percent. Fifth factor i.e. Investment through Portfolio Decision include decision to sell ill performed stock and treatment of Investment Portfolio, explain 9.464 percent of variance and factor loading of these variables are 0.682 and 0.651 respectively and the communality of factors one, two, three, four and five are 51.647 percent.

The variables which are loaded on sixth factor i.e. Satisfaction on Investment in stock market explains 8.613 percent of variance and the communality of factors one, two, three, four, five and six are 60.261 percent.

Table 7:- Factor Analysis.

\begin{tabular}{|c|c|c|c|c|}
\hline Variables & $\begin{array}{l}\text { Factor } \\
\text { Loadings }\end{array}$ & $\begin{array}{l}\text { Factor } \\
\text { Order }\end{array}$ & $\begin{array}{l}\text { Labelling of } \\
\text { the Factor }\end{array}$ & $\begin{array}{l}\text { Total } \\
\text { Variance } \\
\text { Explained } \\
\%\end{array}$ \\
\hline Comparison among Investors for Picking Better stock & .764 & \multirow[t]{2}{*}{ Factor 1} & \multirow{2}{*}{$\begin{array}{l}\text { Knowledge } \\
\text { about } \\
\text { Investment } \\
\text { Decision }\end{array}$} & \multirow[t]{2}{*}{11.898} \\
\hline $\begin{array}{l}\text { Avoidance to make Investment Companies having poor } \\
\text { earning History }\end{array}$ & .652 & & & \\
\hline $\begin{array}{l}\text { Action regarding stay on previous investment coz of } \\
\text { poor market performance }\end{array}$ & .719 & \multirow[t]{2}{*}{ Factor 2} & \multirow{2}{*}{$\begin{array}{l}\text { Awareness } \\
\text { about } \\
\text { Investment } \\
\text { Decision }\end{array}$} & \multirow[t]{2}{*}{10.460} \\
\hline Perception regarding to avoid to buy expensive Stock & .618 & & & \\
\hline $\begin{array}{l}\text { Comparison among Investors for willing High Risk } \\
\text { Investment }\end{array}$ & .800 & Factor 3 & $\begin{array}{l}\text { Understanding } \\
\text { of Investment } \\
\text { Decision }\end{array}$ & 10.042 \\
\hline Tolerance of Risk for High Return & .803 & \multirow[t]{2}{*}{ Factor 4} & \multirow{2}{*}{$\begin{array}{l}\text { Professional } \\
\text { skill in } \\
\text { Investment } \\
\text { Decision }\end{array}$} & \multirow[t]{2}{*}{9.783} \\
\hline Consultancy for making Investment & .522 & & & \\
\hline $\begin{array}{l}\text { Perception regarding decision for sell of stock which } \\
\text { was hit light in past year }\end{array}$ & .682 & \multirow[t]{2}{*}{ Factor 5} & \multirow{2}{*}{$\begin{array}{l}\text { Investment } \\
\text { through } \\
\text { Portfolio }\end{array}$} & \multirow[t]{2}{*}{9.464} \\
\hline Treatment of Investment Portfolio Element & .651 & & & \\
\hline
\end{tabular}




\begin{tabular}{|l|l|l|l|l|}
\hline Satisfaction regarding Investment decision & & Decision & \\
\hline & .805 & Factor 6 & $\begin{array}{l}\text { Satisfaction } \\
\text { on Investment } \\
\text { in } \\
\text { market }\end{array}$ & 8.614 \\
stock & & \\
\hline
\end{tabular}

\section{Conclusion:-}

The study based on investors consideration for investment decision in stock market concluded that majority of investors consider that tolerance of risk for high return, consultancy for making investment, comparison among investors for picking better stock, avoid investing in companies having poor earning history, comparison of price with previous high and low, selling the stock less remunerative hold on previous investment due to poor market performance, price fluctuations are taken into account while making investment in stock market. However, the mean score of responses on the statements comparison among willing to take high risk investment, skill regarding past investment and treatment of investment portfolio was found slightly above the average mean score. However, significant difference has been observed in the investor's consideration while making investment decision in stock market. 